\title{
Quality of service in the Heineken supply chain, México: an empirical investigation in the west of Mexico
}

\section{Calidad de servicio en la cadena de suministro de Heineken, México: una investigación empírica en el occidente de México}

\author{
PÉREZ-CRUZ, Omar Alejandro*†, AMEZCUA-VIVAS, José de Jesús, MEJÍAS-BRITO, Johann and \\ TEJEDA-CASTREJÓN, Jesús Francisco
}

Universidad de Colima. Faculty of Accounting and Administration, Colima, Mexico.

Tecnologico Nacional de Mexico / Instituto Tecnologico de Colima, Colima, Mexico.

ID $1^{\text {st }}$ Author: Omar Alejandro, Pérez-Cruz / ORC ID: 0000-0003-3367-8259

ID $1^{\text {st }}$ Coauthor: José de Jesús, Amezcua-Vivas / ORC ID: 0000-0003-4009-9124

ID $2^{\text {nd }}$ Coauthor: Johann, Mejías-Brito / ORC ID: 0000-0001-6226-6830

ID $3^{\text {rd }}$ Coauthor: Jesús Francisco, Tejeda-Castrejón / ORC ID: 0000-0001-7809-7437

DOI: $10.35429 / J B D S .2020 .18 .6 .1 .8$

Received July 10, 2020; Accepted December 30, 2020

\begin{abstract}
The general objective of this work is to analyze the quality factors of the supply chain service in the western regional direction of the company Cervezas Cuauhtémoc Moctezuma - Heineken México. The analysis was framed in a model proposed by Gohain, Thambiah and Hong (2018) which measures six dimensions of service quality: the object, the process, the infrastructure, the interaction, the environment and social responsibility. A survey was applied as an instrument to collect the responses of active providers in the western region of Mexico. The results were estimated by using STATA 14 to evaluate the relationship between the proposed factors. The results highlight that the quality of the supply chain is influenced by the quality criteria of the product, the process and the interaction. In this way, this research contributes with relevant information that allows them to make quick and practical decisions to use those responsible for the company's supply chain, as well as other economic sectors.
\end{abstract}

Supply chain, Service quality, Suppliers, Logistics regression

\begin{abstract}
Resumen
El objetivo general del presente trabajo es analizar los factores de calidad del servicio de la cadena de suministro en la dirección regional occidente, de la empresa Cervezas Cuauhtémoc Moctezuma - Heineken México. El análisis se enmarcó en un modelo propuesto por Gohain, Thambiah y Hong (2018) el cual mide de seis dimensiones de la calidad del servicio: del objeto, del proceso, de la infraestructura, de la interacción, del ambiente y de la responsabilidad social. Se aplicó una encuesta como un instrumento para recopilar las respuestas de los proveedores activos en la región occidente de México. Los resultados fueron estimados mediante el uso de STATA 14 para evaluar la relación entre los factores propuestos. Los resultados destacan que la calidad de la cadena de suministro se ve influenciada por los criterios de calidad del producto, del proceso y por la interacción. De este modo, esta investigación contribuye con información relevante que les permita tomar decisiones rápidas y prácticas de usar a los responsables de la cadena de abastecimiento de la empresa, así como de otros sectores económicos.
\end{abstract}

Cadena de suministro, Calidad del servicio, Proveedores, Regersión logística

Citation: PÉREZ-CRUZ, Omar Alejandro, AMEZCUA-VIVAS, José de Jesús, MEJÍAS-BRITO, Johann and TEJEDACASTREJÓN, Jesús Francisco. Quality of service in the Heineken supply chain, México: an empirical investigation in the west of Mexico. Journal of Business Development Strategies. 2020. 6-18:1-8.

\footnotetext{
* Correspondence to Author (email: omar_perez@ucol.mx)

$\dagger$ Researcher contributing first author.
} 


\section{Introducction}

The evaluation of suppliers is one of the fields of the supply chain (CS) with contributions to management, since the impact on costs and inventories is decisive for the effectiveness of company operations (Arango-Serna, AdarmeJaime, \& Zapata-Cortes, 2013).

Currently, competitiveness, technological changes, the ephemeral life cycles of goods, the reduction of hidden costs, the outsourcing of these, digital business opportunities, as well as the trend towards sustainable businesses, have led companies to focus to improve their processes to be able to stand out from their competitors. This makes it necessary for companies to direct their attention to the management of suppliers, in such a way that they can control costs, losses and increase the efficiency of their operations. These actions also make it possible to take care of the relationship with customers, the levels of service, the efficient response to the customer, as well as their satisfaction.

From previous decades, business efficiency strategies include improvements in logistics and supply systems, as evidenced by studies on warehouse management (Mejía \& Higuita, 2015) and service strategies according to customer needs (Correa, Gómez, \& Cano, 2010).

Currently, research on the supply chain to make purchases of goods and services is focused on generating models that obtain different variables from the decision process.

A supply chain is an integrated process in which two or more companies (such as suppliers, distributors and manufacturers) coordinate the sale of raw materials, for the transformation of final products and / or the marketing of the latter for the sale of details. The number of nodes, stages and the structure of the flow of materials and information contributes to determining the complexity of the supply chain (Arango-Serna, AdarmeJaime, \& Zapata-Cortes, 2013). The models for planning a CS operation can be classified into three groups (Mejía \& Higuita, 2015): strategic, tactical and operational.
Strategic models work with horizons of five to ten years, and affect the long-term performance of the system from a CS planning and design perspective. The operational models work with very small intervals of time, from one to two weeks, and consider the sequencing of operations and timing of productive tasks. Finally, the tactical models are located in the middle of the previous ones. These models work with planning horizons of one to two years, and incorporate some characteristics of both the operational and strategic models (Pérez-Armayor, León-Alen, Racet-Valdés, \& Díaz-Batista, 2013).

According to Ruiz, Ablanedo and Ayala (2012) they manage related variables in a SWOT analysis (Strengths, Opportunities, Weaknesses and Threats) for each provider. These authors point out the importance of knowing the strengths and weaknesses of the providers, lies in identifying in which activities they are competent to continue developing both the provider that owns them and the rest of the providers, in order to develop them with the appropriate characteristics for the supply chain of goods and services they perform, benefiting CM with competent suppliers. On the other hand, for Zutshi and Creed (2009) the weaknesses are important to know about them, since they create inconveniences in the established plans. Resulting in not meeting the supply chain objectives and eliminating them, the analyzed company is being further strengthened, ensuring the success of the established objectives.

A current indicator to consider when choosing suppliers is to take them as an integral part of the supply chain. In this regard, Vijay, (2006) and Jae-Eun and Brenda, (2008) establish that no company competes alone. With this principle, they establish that integration and management in interaction with suppliers are registered today as one of the important columns for sustainable competitive advantage. For Araz, and Ozkarahan (2007), the supplier-client relationship is established by proposing a model in supplier management that allows building relationships of mutual trust, increasing the scope of planning and the level of cooperative activity. 
For Narasimhan, Talluri, and Méndez, (2004), the establishment of partnerships and alliances between companies and their suppliers is an important manifestation of their ability to acquire competitive advantages.

In accordance with the above, it is important to mention the importance of identifying a reliable supplier base to develop them and make them business partners; those who do not have the necessary participation characteristics for the purchasing company will need to be eliminated from the supplier base with which is counted. Pérez-Armayor, LeónAlen, Racet-Valdés and Díaz-Batista (2013), establish that it is necessary to develop a requalification process towards suppliers in order to reduce it and have a smaller set of possible suppliers.

That is why, the evaluation of suppliers is one of the fields of greatest interest for both academics and entrepreneurs, due to the effect it has on cost control, as well as on the improvement of the level of service in CS, both for suppliers as for buyers. Thus, this article analyzes the quality factors of the supply chain service in the western regional direction of the company Cervezas Cuauhtémoc Moctezuma Heineken México.

The article is organized as follows. The conceptual framework is first exposed. Subsequently, the methodology implemented for the analysis of the information is exposed. Finally, the conclusions and future lines of research are explained.

\section{Literature Review}

\section{Supply chain}

According to Handfield and Nichols (1999), supply chains include all those activities associated with the flow and transformation of products from raw materials or inputs directed to the final consumer.

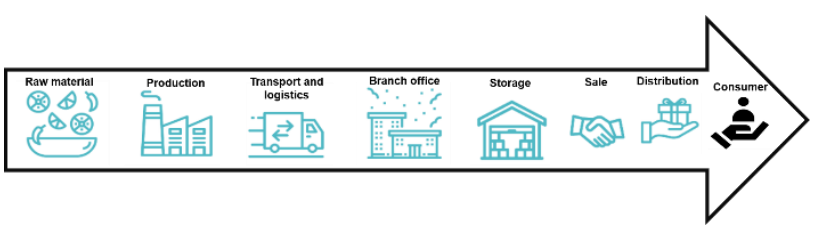

Figure 1 Representation of the basic elements of a supply chain
For the study company it is of utmost importance to have commercial partners committed to the quality of service in the supply chain and in each of its activities carried out in the transformation of raw materials to required products, hence the importance of the study carried out, with the aim of knowing areas of opportunity both internally and externally and developing strategic plans to improve the execution processes of this. Achieving an optimal two-way partnership between organizations is achieved through effective management of service indicators and a clear understanding of the needs of both parties. For Grönroos (1994), the quality of the service depends on the comparison of the expected service with the perceived service.

Currently, in accordance with the demands of globalization, it is of utmost importance to establish competitive advantages in supply chains that allow adaptation to dynamic changes in markets. Profitability and shorter delivery time are some indicators that are optimized by improving Supply Chain. For this reason, it is important to standardize the quality of the supply chain service and thus perform excellent performance, which in turn enables savings to be generated and is reflected in the increase in utility and customer satisfaction.

For this reason, it is of utmost importance to constantly work on developing the supply chain, seeking to be effective in the competitive environment in which it develops, analyzing the opportunities and threats to have an advantage over the competition, such advantage should be used to stay in the competitive market in which it develops. According to Chen and Li (2005), who stated that establishing a sourcing strategy allows lasting competitive advantages to be achieved, by strengthening relationships with suppliers and open communication between members of the supply chain, this collaboration creates a business strategy in order to optimize the relationship with the manufacturer, distributor and customer. 
To ensure the excellent performance of the supply chain, it is advisable to effectively evaluate and select the best suppliers, in this way the development of the suppliers guarantees and improves their long-term performance, establishing joint work plans in a competitive manner. . For Narasimhan, Talluri, and Méndez, (2004), the establishment of partnerships and alliances between companies and their suppliers is an important manifestation of their ability to acquire competitive advantages. Main aspect to guarantee the quality of the supply chain service and thus generate better levels of competitiveness in the purchasing process by knowing how to select and evaluate correctly and in a timely manner the supplier base with which it has.

The constant changes in consumer tastes make it necessary that, although there is already a developed supplier base, sometimes new suppliers must be acquired, being the step that takes the most time for the evaluation process, since it must search for and know your clients, experience, possible certifications, among many other things. In order to identify if they are related to the study company and can cover the needs that are required, without forgetting the follow-up or accompaniment to be carried out so that the new supplier becomes familiar with the way the company operates, payment conditions, quality policies, delivery times among many other things.

Together, it is important to acknowledge the contributions of Vollmann, William, and Waybark. (2005), establish a set of world-class actions important for successful integration and development with suppliers. These include: the participation of the supplier in the design of new products and processes, the promotion of training programs for suppliers, the transfer of knowledge and the creation of supplier support centers.

Currently it is possible to have fast and timely contact between the fundamental parts of the supply chain, it should not be forgotten that current requirements make delivery times much faster and in turn allow real-time traceability of the movement of goods. For this reason, the supply chain constantly evolves in the tireless search for customer satisfaction.
For the company under study, this evolution, although it provides considerable benefits such as greater knowledge of the products offered by suppliers, also presents considerable challenges.

Such as supporting suppliers in improving their production processes and establishing appropriate conditions for the development of sustainable products, emphasizing the quality of service in the supply chain. Hence the importance of carrying out this study in order to know the indicators that allow the optimum performance of the supply chain of the company under study to be measured and to seek continuous improvement.

In accordance with the aforementioned and for the case of this study, the following indicators are described in order to be able to standardize the quality of service process in the supply chain and identify areas of opportunity, for which reason the following is done description of these.

\section{Quality of service}

A transnational company like the one in this research are more likely to change providers. Quality measurement is one of the research strategies for business. The extensive range of research in this area shows its importance for continuous improvement strategies in companies (Gohain, Thambiah, \& Hong, 2018; Mejía \& Higuita, 2015; Cardona \& Bravo, 2012; Zineldin \& Vasicheva, 2012). Regardless of the fact that research shows sometimes inconsistent results, the field of service quality has led to the development of various theories and service models. One of the pioneers on this issue were Parasuraman and the SERVQUAL model and the Grönroos model and quality gaps. These measures have produced mixed results that encompass the freedom to create and explore new attributes, highlighting the absolute scale of service quality.

\section{Customer satisfaction}

Satisfaction is understood as "the consumer's reaction to the service experience. Customer satisfaction is the main objective of any supply system, as this results in better quality in the customer-supplier relationship. 
The level of satisfaction It is directly perceived only by the person who lives the service experience. Assessing customer satisfaction is finding evidence about the attention given to the structure, processes and results of the services provided.

Thus, the concept of customer satisfaction is key to the continuous improvement of supply chain services. However, there are a multitude of models and dimensions that have been applied and evaluated to different business sectors and sizes, to different social strata, in different contexts and markets, as well as different cultural conditions. Despite this, one of the important reasons for the study of service quality continues to be evaluation from the customer's perspective, which has a direct impact on customer satisfaction.

Therefore, in this research, quality was analyzed based on the model proposed by Gohain, Thambiah and Hong (2018) which measures six dimensions of service quality: the object, the process, the infrastructure, the interaction, environment and social responsibility. These dimensions are defined as:

- $\quad$ Object Quality of Service (CSO): explains the technical quality of the product or central service that the customer receives.

- $\quad$ Process Quality of Service (CSP): explores the quality that the product or service provider gives to the main product or service.

- Infrastructure Quality of Service (CSINF): refers to the resources necessary for the realization of the product or service.

- Interaction Quality of Service (CSINT): Explains the quality of data exchange, financial exchange, and social interaction.

- Environment Quality of Service (CSA): explores the environmental context in which the provider-client relationship occurs, influenced by the functional environment of this interaction.
- Quality of service of social responsibility (CSRS): this indicator measures the feedback on care and the actions that providers carry out in favor of the company and society in general.

\section{Methodology}

The information was collected through a questionnaire self-administered by the providers. Regarding the sample, this was probabilistic, applying the questionnaire to the 248 providers who provide their services to DR West in the states: Jalisco, Colima, Guanajuato, Michoacán, Aguascalientes, Zacatecas. So the selection of variables was as follows:

\begin{tabular}{|c|c|}
\hline Factors & Wu \\
\hline $\begin{array}{l}\text { Service } \\
\text { satisfaction (SS) }\end{array}$ & Satisfaction of the required service \\
\hline $\begin{array}{ll}\begin{array}{l}\text { Object } \\
\text { of }\end{array} & \begin{array}{l}\text { Quality } \\
\text { (CSO) }\end{array} \\
\text { Service }\end{array}$ & $\begin{array}{l}\text { The established time for the } \\
\text { delivery of the product and / or } \\
\text { required service is fulfilled. }\end{array}$ \\
\hline $\begin{array}{l}\text { Process quality } \\
\text { of service (CSP) }\end{array}$ & $\begin{array}{l}\text { It offers guarantee on the product } \\
\text { and / or service that are required } \\
\text { by the client }\end{array}$ \\
\hline $\begin{array}{l}\text { Infrastructure } \\
\text { Quality of } \\
\text { Service (CSINF) }\end{array}$ & $\begin{array}{l}\text { Updates its existence (stock) } \\
\text { according to the new products and } \\
\text { / or services that come onto the } \\
\text { market. }\end{array}$ \\
\hline $\begin{array}{l}\text { Interaction } \\
\text { Quality } \\
\text { Service } \\
\text { (CSINT) } \\
\end{array}$ & $\begin{array}{l}\text { Time to resolve customer } \\
\text { complaints }\end{array}$ \\
\hline \multirow[t]{2}{*}{$\begin{array}{l}\text { Environment } \\
\text { Quality of } \\
\text { Service (CSA) }\end{array}$} & $\begin{array}{l}\text { ¿Do you have policies, programs } \\
\text { and strategies that favor the full } \\
\text { human development of your } \\
\text { collaborators? }\end{array}$ \\
\hline & $\begin{array}{l}\text { ¿Do you provide your } \\
\text { collaborators with the appropriate } \\
\text { personal protective equipment to } \\
\text { carry out their activities and } \\
\text { guarantee their safety and integrity } \\
\text { against the risks of the work they } \\
\text { do? }\end{array}$ \\
\hline \multirow[t]{2}{*}{$\begin{array}{l}\text { Quality of social } \\
\text { responsibility } \\
\text { service (CSRS) }\end{array}$} & $\begin{array}{l}\text { ¿Do you have any certification that } \\
\text { guarantees the efficient use of } \\
\text { water, energy and waste } \\
\text { management produced by your } \\
\text { activity? }\end{array}$ \\
\hline & $\begin{array}{l}\text { ¿Is there feedback from the client } \\
\text { about industrial safety and } \\
\text { environmental impact actions? }\end{array}$ \\
\hline
\end{tabular}

Table 1 Analysis factors 


\section{Research Findings}

As part of the statistical methods applied in this research, there is the correlation analysis, which was applied in order to measure the degree of linear relationship between each of the variables studied. The main statistical method that was used was the logit logistic regression to estimate the causality between the independent variables CSO; CSP; CSINF; CSINT; CSA and CSRS, with the dependent SS. First, the correlation between the established indicators was analyzed, obtaining the following results:

\begin{tabular}{|l|r|}
\hline \multicolumn{2}{|c|}{ Dependent variable } \\
\hline Quality of service (CS) \\
\hline \multicolumn{1}{|c|}{ Independent variable } \\
\hline Object Quality of Service (CSO) & $0.3453^{*}$ \\
\hline Process quality of service (CSP) & $0.4412^{*}$ \\
\hline $\begin{array}{l}\text { Infrastructure Quality of Service } \\
\text { (CSINF) }\end{array}$ & 0.0982 \\
\hline Interaction Quality of Service (CSINT) & $0.2534^{*}$ \\
\hline Environment Quality of Service (CSA) & 0.0909 \\
\hline $\begin{array}{l}\text { Quality of social responsibility service } \\
\text { (CSRS) }\end{array}$ & $0.2070^{*}$ \\
\hline Note: * significant at 0.05. \\
\hline
\end{tabular}

Table 2 Variable correlations

Source: Self made based on STATA 14.

Once the correlation between the indicators to be analyzed was determined, a logit logistic regression was applied for SS \& CSO, CSP and CSINT., Obtaining the following results:

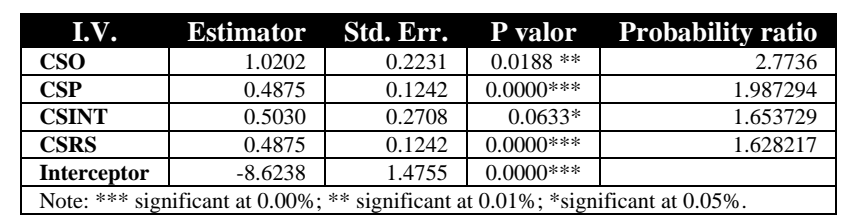

Table 3 Logistic regression logit of supply service satisfaction

Source: Self made based on STATA 14

In the previous results it is observed that the significant and positive indicators were the CSO, CSP, CSINT and CSRS activities. Thus, according to the model proposed by Gohain, Thambiah and Hong (2018) 4 of the 6 dimensions of service quality, related in this research: the quality of service of the object (CSO), of the processes (CSP), interaction (CSINT) and social responsibility (CSRSC).
In operational terms, the satisfaction of the supply service is related to compliance with the established delivery time, compliance with the supplier's guarantee, attention and resolution of complaints, as well as the feedback of activities on safety and environmental impact that the providers perform.

Regarding the probability ratio, it is observed that the CSO factor, in the indicator of compliance with the established delivery time, is 2.77 times more likely to influence service satisfaction. For its part, the CSP factor in terms of compliance with the supplier's guarantee, this is 1.98 times more likely to affect service satisfaction. The CSINT fator in reference to the attention and resolution of complaints, has a 1.65 more probability. Finally, the CSRSC factor in relation to the feedback of the activities on safety and environmental impact that providers carry out, has a 1.62-fold impact on service satisfaction.

Once the factor estimates were obtained, the Analysis of Variance (ANOVA) was applied, where the significance of the variables was checked: SS \& CSO, CSP, CSINT and CSRS.

\begin{tabular}{|c|c|c|c|}
\hline I. V. & LR Chisq & Df & $\operatorname{Pr}(>$ Chisq $)$ \\
\hline $\mathrm{CSO}$ & 30.0478 & 1 & $0.0000 * * *$ \\
\hline CSP & 5.6930 & 1 & $0.0170 * *$ \\
\hline CSINT & 3.4363 & 1 & $0.0637 *$ \\
\hline CSRS & 16.5233 & 1 & $0.0000 * * *$ \\
\hline
\end{tabular}

Table 4 ANOVA test

Source: Self made based on STATA 14

With this analysis anova, it is evident that the factors of the quality of the object (CSO), the process (CSP), the facilities (CSINT) and the social responsibility (CSRS) influence the perceived quality. In this way, the robustness of the analyzes carried out is verified, where the indicators were significant at .01 and at $.001 \%$. 


\section{Discussion and Conclusion}

Based on the information presented in this investigation, it is observed that the main objective was achieved, by evaluating the quality of the service provided in the Heineken company supply chain. The analysis of the evaluated factors allowed knowing the most important factors that determine the quality of the service.

It is observed that the CSO, CSP, CSINT and CSRS factors were significant in relation to the dependent variable. Thus, the indicators of: delivery time, supplier guarantee, attention and resolution of complaints and the feedback of the activities on safety and environmental impact that the suppliers carry out are decisive for the quality of the service. These results are in agreement with that stated by Gohain, Thambiah and Hong (2018).

According to Mantilla and Sánchez (2012), they analyze that the time factor adds value in the supply chain and that it represents $10 \%$; followed by order processing activities (supplier guarantee, attention and resolution of complaints), and logistics activities (safety and environmental impact).

Continuing with the above, the tangible elements (CSO and CSP), together with the intangible elements (CSINT and CSRS) are decisive for the quality of the service. In this way, it can be argued that supplier evaluation is a fundamental part of the supply chain, due, among other things, to the fact that it is the starting point for marketing companies as the case study of this research.

\section{Suggestions for future research}

It is for this reason that the constant evaluation of the quality of the service contributes to the identification of areas of opportunity within the productive system of any company, thus contributing to the continuous search for effective strategies that allow continuous improvement. The orientation to improve satisfaction levels, either in services or products, is to identify and adjust to the needs of the market.
The work of senior management requires identifying these areas of opportunity to manage a change that contributes to solving problems, whether in processes, delivery or after-sales service, thus achieving leverage competitive advantages.

\section{Research limitation}

Among the possible limitations presented by this research, the lack of complexity in the analyzed variables can be mentioned. As future lines of research in this topic is the analysis of more cases of application of the factors found, related to additional elements of companies such as size, seniority, educational level of the manager, among other characteristics to validate different companies in other sectors. and sizes.

\section{References}

Arango-Serna, M., Adarme-Jaime, W., \& Zapata-Cortes, J. (2013). Inventarios colaborativos en la optimización de la cadena de suministros. DyNA, 80(181), 71-80.

Cardona, M., \& Bravo, J. (2012). Service quality perceptions in higher education institutions: the case of a colombian university. Estudios Gerenciales, 28(1), 23-29. Obtenido de www.elsevier.es/estudios_gerenciales

Chacón, J., \& Moreno, C. (2016). Organizational antecedents and capabilities for sustainable supply chain management in developing economies: The case of Colombian focal firms. Cuadernos de Administración, 29(53), 101-146. doi:https://doi.org/10.11144/Javeriana.cao2953.oacs

Chen, K., y Li, R. (2005). Supplier's capability and price analysis chart. International Journal of Production Economics, 98 (3), 301-315.

Correa, A., Gómez, R., \& Cano, J. (2010). Gestión de de las Tecnologías de la Información y Comunicación (TIC). Estudios Gerenciales, 26(117), 145-171. doi:https://doi.org/10.1016/S01235923(10)70139-X 
Gohain, K., Thambiah, S., \& Hong , T. (2018). A Comprehensive Model with Six Service Quality Dimensions, Satisfaction and Loyalty: An Empirical Investigation into the Public Hospitals in Malaysia. International Journal of Economic \& Management Sciences, 7(1), 1-4. doi:https://doi.org/10.4172/2162-6359.1000508

Grönroos, C. (1978). A Service Oriented Approach to Marketing of Services. European Journal of Marketing, 12(8), 588-601.

Handfield, R., y Nichols, E. (1999). Introduction to Supply Chain Management. Englewood Cliffs. New Jersey 07458, USA. Huish, P.

Mantilla, O. L., \& Sánchez, J. M. (2012). Modelo tecnológico para el desarrollo de proyectos logísticos usando Lean Six Sigma. Estudios Gerenciales, 28(124), 23-43. doi:https://doi.org/10.1016/S0123-

5923(12)70214-0

Mejía, C., \& Higuita, C. (2015). Costo de servir como variable de decisión estratégica en el diseño de estrategias de atención a canales de mercados emergentes. Estudios Gerenciales, 31(134), 50-61. doi:https://doi.org/10.1016/j.estger.2014.08.006

Narasimhan, R., Talluri, S. and Méndez, D. (2004). Supplier evaluation and nationalization via data envelopment analysis: An empirical examination.

Palacios-Duarte, P., Pérez-Paredes, A., \& Torralba-Flores, A. (2019). Bounded financial rationality by owners or administrators of mexican micro-enterprises. Cuadernos de Administración, $\quad 35(64), \quad 78-95$. doi:https://doi.org/10.25100/cdea.v35i64.6355

Pérez-Armayor, D., León-Alen, E., RacetValdés, A., \& Díaz-Batista, J. (2013). Funcionalidades de Sistemas de Planificación de Recursos Empresariales para Cadenas de Suministro. Ingeniería Industrial, 34(2), 155166.

Porter, M. (2009). Estrategia competitiva técnicas para el análisis de la empresa y sus competidores. Madrid: Pirámide.
Vollmann, T., William, B. and Waybark, D. (2005). Manufacturing planning and control for supply chain Management. New York: Mc Graw Hill Irwin.

Zineldin , M., \& Vasicheva , V. (2012). The Implementation of TRM Philosophy and 5Qs Model in Higher Education - An Exploratory Investigation at a Swedish University. Nang Yan Business Journal, 1(1), 66-75. doi:https://doi.org/10.2478/nybj-2014-0010 